\title{
The Model of Purchase Decision in The Online Stores Application: Integration of Technology Acceptance Model, Personal Factors, Product Quality, and Price
}

\author{
Received: \\ 29 Juli 2021 \\ Revision \\ received: \\ 30 Juli 2021 \\ Accepted: \\ 4 Agustus 2021 \\ Sharnuke Asrilsyak ${ }^{1 *}$, Yuliarni Putri ${ }^{2}$, Abdul Malik Sayuti ${ }^{3}$, Chandra Budhi \\ Septyandi ${ }^{4}$, dan Wahyu Rafdinal ${ }^{5}$ \\ ${ }^{1}$ Program Studi Manajemen, Universitas Riau, Indonesia \\ ${ }^{2}$ Program Studi Manajemen Retail, Universitas Taman Siswa, Indonesia \\ ${ }^{3}$ Program Studi Administrasi Bisnis, Politeknik Negeri Bandung, Indonesia \\ ${ }^{4}$ Program Studi Usaha Perjalanan Wisata, Politeknik Negeri Bandung, Indonesia \\ ${ }^{5}$ Program Studi Manajemen Pemasaran, Politeknik Negeri Bandung, Indonesia
}

\begin{abstract}
:
This study aims to analyze the factors which influence an individual in making a purchase in online stores. It investigates the factors of technology acceptance (theory of acceptance model), personal (lifestyle and trust), product quality, and price in an online store. There are 180 who have bought products in the online stores. The data analysis technique used is the Structural Equation Model based on Partial Least Square. The results prove that from the technology acceptance explained by TAM indicates that only perceived usefulness significantly influential toward attitude. Then, it also denotes that attitude, product quality, price, lifestyle, and trust can influence purchase decisions in the online store applications by explaining the relation among technology acceptance models, personal factors (lifestyle and trust), product quality, and price.
\end{abstract}

Keywords: technology acceptance model, product quality, price, lifestyle, trust, purchase decision

\begin{abstract}
Abstrak:
Penelitian ini bertujuan untuk menganalisis faktor-faktor yang mempengaruhi seseorang dalam melakukan pembelian di toko online. Ini menyelidiki faktor penerimaan teknologi (teori model penerimaan), pribadi (gaya hidup dan kepercayaan), kualitas produk, dan harga di toko online. 180 responden diilih yaitu responden yang telah membeli produk di toko online. Teknik analisis data yang digunakan adalah Structural Equation Model berbasis Partial Least Square. Hasil penelitian membuktikan bahwa dari penerimaan teknologi yang dijelaskan oleh TAM menunjukkan bahwa hanya persepsi kegunaan yang berpengaruh secara signifikan terhadap sikap. Kemudian, sikap, kualitas produk, harga, gaya hidup, dan kepercayaan dapat mempengaruhi keputusan pembelian pada aplikasi toko online. Penelitian ini dapat memberikan pemahaman mengenai penerimaan teknologi, faktor personal (gaya hidup dan kepercayaan), kualitas produk, dan harga.
\end{abstract}

Kata kunci: model penerimaan teknologi, kualitas produk, harga, gaya hidup, kepercayaan, keputusan pembelian

\section{Introduction}

The online shop concept makes transactions more accessible and faster. In online purchases, various conveniences are obtained through online purchases such as more time-saving, more comfortable to buy and pay, being able to compare with other online stores, to find references from previous buyers, 
many available product choices, and competitive prices. This excellence is obtained if this application can serve easiness and benefit to the users, as explained in the technology acceptance model (M. Lee et al., 2010). The ease of use of online marketplace applications makes consumers comfortable shopping (Yang et al., 2017). In addition, perceived usefulness of buying at an online store can influence the attitude and online purchases (Hamari \& Keronen, 2017). Ease of use can be an initial stage of acceptance of innovation and important for adoption and use in the future (Davis, 1989). Thus, both factors (perceived ease of use and perceived usefulness) are important to scrutinize its influence toward the attitude which later affect the purchase decision in online store applications.

Other than technologies explained in TAM (perceived ease of use and perceived usefulness), personal factors, namely lifestyle and trust, are also crucial. Lifestyle is a decorative roadway of life in which people fit themselves (Havighurst \& Feigenbaum, 1959). A person's lifestyle is a pattern of one's life in daily life which is expressed in activities, interests, and opinions in question. From a marketing point of view, the lifestyle of people has differentiated themselves into different groups based on their shared interests such as their work habits, spending their time and money into different activities (Ahmed, 2015). It indicates that lifestyle and consumer purchases are interrelated. Everyone has a different lifestyle that will differentiate the way they shop. Therefore, it is important to analyze lifestyle as a personal factor influencing purchase decisions. Then, trust is another pivotal factor to attract new customers (Boonlertvanich, 2019). Some previous studies also denote that trust influences the purchase decision (Hosseini \& Norouzi, 2017; Mohmed et al., 2013; Tasin, 2017). Thus, it is crucial to analyze one's trust toward the purchase decision at online stores applications.

Beside technology (TAM) and personal factors (lifestyle and trust), product quality and price also play important roles in influencing the purchase decision. The quality given to the consumers will influence their Purchase Decision (W. I. Lee et al., 2017). Quality is a subjective problem in which every individual defines it differently (Lew \& Sulaiman, 2014). Every online store has many types of products with various qualities. it must pay attention to the core and added value of the products that can meet the needs and desires of consumers (Hashim \& Hamzah, 2014). On price factor, the perception of the reasonableness of prices is one of the most important reasons consumers remain with current providers or move on to others (Han, 2015). In the context of online markets, everyone can freely compare prices. It is important to analyze whether prices make a considerable contribution in influencing purchasing decisions in the context of online stores.

This research is limited to the scope of consumers in Indonesia. There are various reasons why Indonesia is chosen because: (1) Based on the listing result in 3,504 census blocks by BPS (Badan Pusat Statistik/Central Bureau of Statistics), it was recorded that as many as $15.08 \%$ of businesses selling goods / services via the internet, of the recorded number, $72.83 \%$ of businesses selling goods / services via the internet; (2) Most businesses started selling online from 2017 to 2018, amounting to $45.31 \%$; (3) Of the 13,485 e-commerce businesses, 17.21 trillion of business revenue from sales via the internet were obtained with a total of 24.82 million online sales transactions (Badan Pusat Statistik, 2019). Judging from the great prospects in the business environment, it is important to make Indonesian consumers the respondents of this study

This research explores the factors that can influence someone in shopping online. Technology acceptance models, personal factors (lifestyle and trust), product quality, and price become some factors in analyzing purchasing decisions at online stores.

\section{Literature Review \\ Online Purchase Decision}

Purchasing decisions are the result of a series of activities carried out by consumers in identifying needs, searching for information, evaluating several alternatives, and choosing the right one (Rafdinal, 2019). In making purchasing decisions, consumers will evaluate product performance by assessing additional features (Lew \& Sulaiman, 2014). Purchasing decision making is influenced by many factors, including store promotion, atmosphere, level of cleanliness, service level, price, value, logistical convenience, and retail experience (Blackwell et al., 2006). Decision making categories are nominal, limited, and broad (Hawkins et al., 2001). The consumer decision-making model consists of six interrelated variables: message, brand recognition, brand attitude, self-confidence, intention, and purchase (Howard, 1989). Brand recognition, attitude and self-confidence are three core factors that shape the consumer 
image of a brand (Vatjanasaregagul \& Thammathirat, 2007). The decision to shop online is the tendency of someone to make purchases through the internet. The tendency in question is experienced through the purchasing process from the search stage to the stage of the purchase decision, not only the intention to make an online purchase. Specifically, in the consumer purchasing process, the decision to shop online is located at the alternative evaluation stage, because at this stage the consumer chooses product attributes.

\section{Technology Acceptance Model (TAM)}

The technology acceptance model explains the factors that determine the use of information technology. The technology acceptance model in this study is divided into two important variables, perceived usefulness and perceived ease of use. Originally developed by Davis (1989), the technology acceptance model (TAM) has emerged as a powerful model and is widely used in various studies relating to the adoption and use of information technology (Yousafzai et al., 2010). TAM emphasizes the importance of perceived ease of use and perceived benefits as two main determinants of technology acceptance (X. Wang \& Goh, 2017). TAM shows that online store user perceptions of the extent to which features in an online store application are easy to use affect perceptions about the usefulness of online store applications (M. Lee et al., 2010). Perceived benefits can improve the performance of work then becomes an important aspect of TAM that can affect the use of technology applications (Davis, 1989) The perceived usefulness of buying at an online store is defined as a sense of usefulness in making online purchases (Hamari \& Keronen, 2017). The value of involvement is influenced by the perceived positive usefulness (Yang et al., 2017) ease of use is an important factor in technology acceptance factors that must be considered. Ease of use can be an initial stage of acceptance of innovation and important for adoption and use in the future (Davis, 1989). Perceived ease of use is also an important factor that can influence the behavior intention and attitude (Yang et al., 2017). Sehingga, hipotesis yang dibangun adalah sebagai berikut:

H1. Perceived ease of use is significantly influential toward attitude

$\mathrm{H} 2$. Perceived usefulness is significantly influential toward attitude

H3: Attitude is significantly influential toward purchase decision

\section{Trust and Lifestyle}

Trust is the foundation of business. Building trust can be difficult in online situations; companies apply strict regulations to their online business partners compared to other partners. In online transactions, trust arises when those involved have received certainty from other parties, and are willing and able to provide their obligations. Trust that is influenced by the quality of information, reviews of previous purchases, and the quality of online sites have an influence on online Purchase Decision (Tasin, 2017). Familiarity with store brands and brands has a positive and significant influence on consumer loyalty and Purchase Decision, and trust moderates the effect on loyalty and Purchase Decision (Hosseini \& Norouzi, 2017). Knowledge is positively related to trust and online shopping activities (C. Wang \& Chen, 2009). In other words, people who know more about shopping online will trust and shop more online. There is a significant influence of social media on online clothing buying behaviour with trust as the most significant element influenced by perceived risk and information seeking behaviour (Chaturvedi et al., 2016). Furthermore, Trust, Previous Experience, and Social which has a strong relationship with the decision to buy online (Mohmed et al., 2013). All of these factors have a positive correlation with buyer intention and buying behaviour.

Consumers develop a set of conceptions that minimize the incompatibility or inconsistency in their lifestyles. People use conceptions such as lifestyle to analyze events that occur around themselves and to interpret, conceptualize, and predict events. The lifestyle concept was first told by Bell, to understand consumer behavior in 1958 (Rainwater et al., 1959). Lifestyle is a decorative roadway of life in which people fit themselves (Havighurst \& Feigenbaum, 1959). This indicates that lifestyle and consumer purchases are interrelated. Lifestyle becomes a differentiating factor for dividing the market into several segments while still paying attention to target customers that are not portrayed by demographics. Many researchers have studied people's lifestyles to get detailed information about it because demographics only provide a little description of the information that makes the marketers get 
hindrance in segmentation (Cooper, 1984). Lifestyle is the pattern of life of a person expressed in his desires, interests and opinions in spending his money and how to allocate time. The main factors forming the lifestyle can be divided into two, namely demographically and psychographically. Demographic factors are based on education level, age, income level and gender, while psychographic factors are more complicated because of the indicators of their compilation of consumer characteristics. H4. Trust is significantly influential toward purchase decision

H5. Lifestyle is significantly influential toward purchase decision

\section{Product Quality and Price}

Products are everything that can be offered to the market to satisfy a desire or need, including physical goods, services, experiences, events, people, places, property, organizations, information, and ideas. Product quality shows the length of the product's size, the product's trustworthiness, product accuracy, ease of operation and maintenance, and other attributes assessed. Products can be in the form of physical objects or services offered to consumers who are willing to pay (Išoraitė, 2016). In conducting a product offering to customers, it must pay attention to the core and added value of the products that can meet the needs and desires of consumers (Hashim \& Hamzah, 2014). It indicates that product quality can be significantly influential toward the purchase decision.

The price to the consumer could provide insight into the value of which is owned by a product (Išoraite, 2016). Whereas cost, competitors, and customer value are important aspects in determining pricing strategies (Pogorelova et al., 2016). The term 'price' has both monetary and non-monetary aspects. The monetary aspect is the objective price (e.g., the actual price) of a product or service, while the non-monetary aspect is the price perceived by the consumer (e.g., the encoded price) (Zeithaml, 1988). price is inversely proportional to the likelihood that consumers will buy a product or service (Kukar-Kinney et al., 2012). This means the higher the price, the less likely it is that consumers will purchase a product or service given that all other factors remain constant. Therefore, the proposed hypotheses are as follows:

H6. Product quality is significantly influential toward purchase decision

H7. Price is significantly influential toward purchase decision

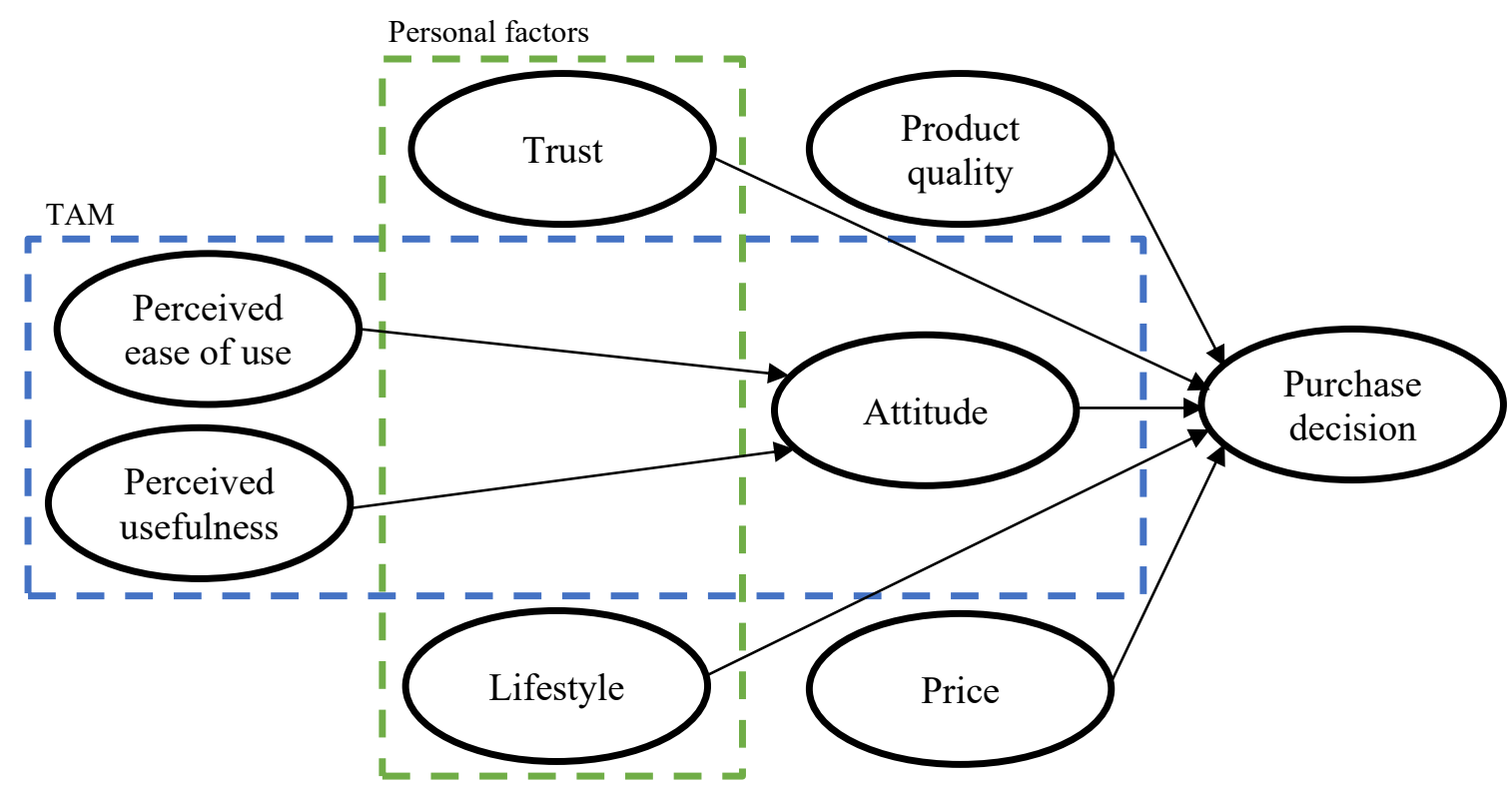

Figure 1. Conceptual Framework

\section{Method}

The sample was taken from the buyers in the online store applications in Indonesia. Sampling method used was the non-probability as the populace researched was unlimited (the total and members of the populace were unknown). It applied a convenience sampling technique, i.e. sampling procedure which chose the samples from the people or easiest units found or accessed with the total samples as many 
as 180 respondents. The data were obtained through sharing questionnaires to the respondents. The first questionnaire was written in English, and later translated into Indonesian. It was then re-translated into English to check its accuracy. The data analysis technique used was Structural Equation Modeling (SEM) based on variance (SEM-PLS). This technique is recognized for estimating path coefficients in structural models (Hair et al., 2017). There were two stages in SEM-PLS analysis namely, analyzing the measurement model and analyzing the structural model. It was selected as it allowed to analyze latent constructs with medium and small sample sizes, and when the data distribution is not normal (Chin et al., 2008).

\section{Result}

Based on the calculation result of SEM-PLS, it shows that the TAM variable, i.e. variable of perceived ease of use, is not significantly influential toward attitude $(\beta=-0.125 ; p=0.094)$, while perceived of usefulness has a significant influence toward attitude $(\beta=0.315 ; \mathrm{p}=0.000)$. Attitude is significantly influential toward the purchase decision $(\beta=-0.233 ; \mathrm{p}=0.001)$. Then, personal factor, i.e. trust, has a significant influence toward purchase decision $((\beta=0.235 ; \mathrm{p}=0.001)$ and so does lifestyle toward purchase decision $(\beta=0.193 ; \mathrm{p}=0.007)$. Next, purchase decision is also influenced by product quality $(\beta=0.308 ; p=0.000)$ and price $(\beta=0.310 ; p=0.000)$. These results point out that purchase decision is the most highly influenced by price and product quality. However, trust and lifestyle are also significantly influential toward the purchase decision. On the TAM model, perceived ease of use does not significantly influence attitude, while perceived usefulness has a significant influence toward attitude.

Table 1. Influence between variables

\begin{tabular}{|l|c|c|l|l|}
\hline Variables & $\begin{array}{c}\text { Path } \\
\text { coefficient }\end{array}$ & $\begin{array}{c}\text { T } \\
\text { Statistics }\end{array}$ & P values & Result \\
\hline H1. Perceived ease of use -> attitude & -0.126 & 1.677 & 0.094 & Rejected \\
\hline H2. Perceived usefulness -> attitude & 0.315 & 3.632 & 0.000 & Accepted \\
\hline H3. Attitude -> purchase decision & 0.233 & 3.110 & 0.001 & Accepted \\
\hline H4. Trust $>$ purchase decision & 0.235 & 3.300 & 0.001 & Accepted \\
\hline H5. Lifestyle -> purchase decision & 0.193 & 2.689 & 0.007 & Accepted \\
\hline H6. Product quality -> purchase decision & 0.308 & 4.539 & 0.000 & Accepted \\
\hline H7. Price -> purchase decision & 0.310 & 4.779 & 0.000 & Accepted \\
\hline
\end{tabular}

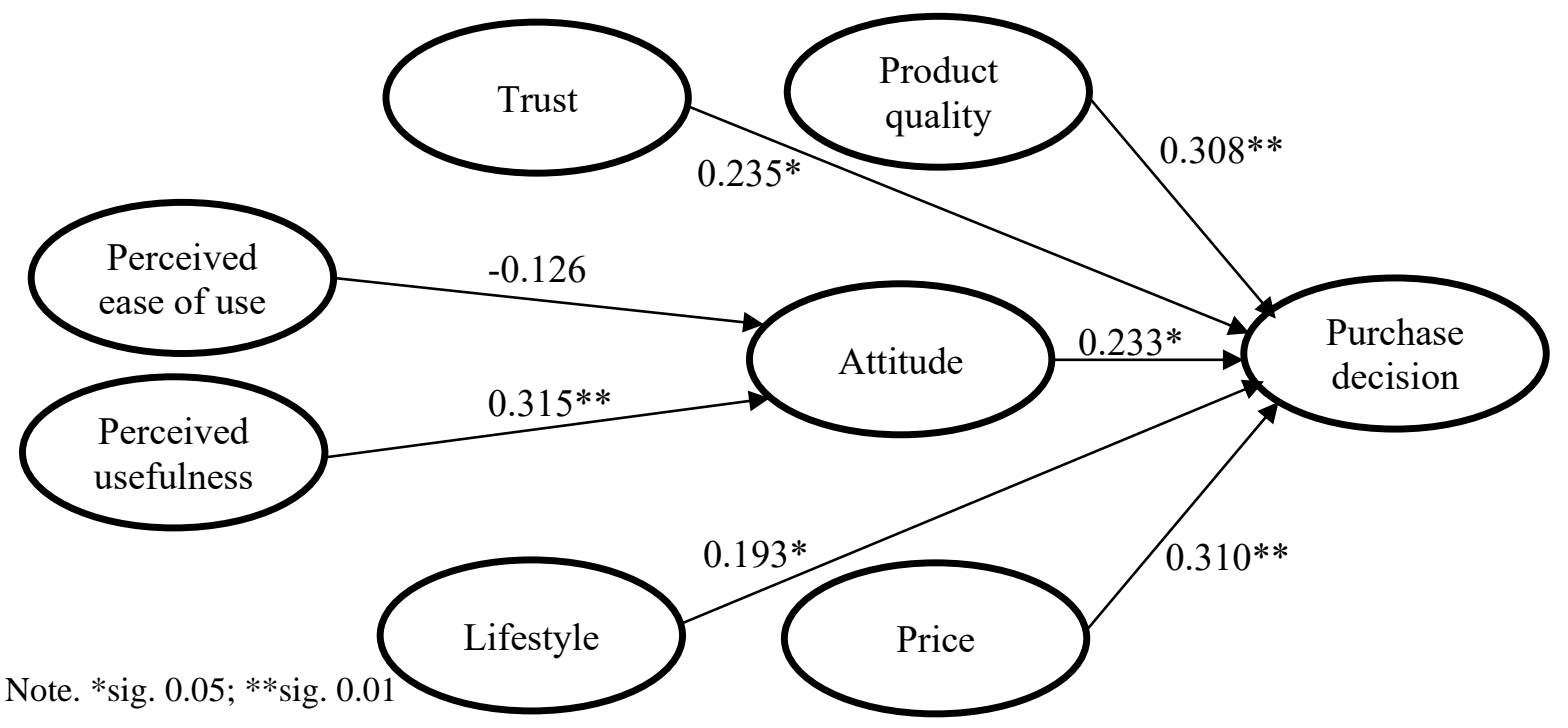

Figure 2. The result model

\section{Discussion}

The research result denotes the important role of technology acceptance factor (technology acceptance model), personal factors (trust and lifestyle), product quality, and price toward purchase decision on an online store. On the technology acceptance factor, perceived usefulness has a significant influence on 
attitude considering that online market applications are very useful in increasing the effectiveness of customer's shopping activities. The usefulness of online market applications such as the convenience of the shopping process, easy comparing products, comparing prices, looking at reviews of previous buyers, seeing product info, and the ability to support activities can influence someone to shop online. Online market application developers need to increase the usefulness of online market applications. The results of this study do not fully support the concept of TAM. The perceived ease of use does not affect consumers attitude in shopping online. This proves that the ease of use of online store applications is not an important factor in attitude at online stores.

On personal factors, the analysis result indicates that lifestyle has a positive and significant influence on the purchase decision in the online stores. Two factors significantly influence the purchase decision, namely social factors (activity, social community, location, and future) and identity factors (work and design tastes) on home purchases simple health. Lifestyle predicts the influence on impulse buying behavior (Ahmed, 2015). When discussing lifestyle, especially in the context of purchasing decisions at online stores, differences in the lifestyle of each individual can affect decisions in making purchases at online stores in general. Then, trust also has a positive and significant influence toward the purchase decision. Consumers' trust in one component of the e-marketplace merchant may not only affect their trust in the other but also influence the way consumers make online purchases (Hong, 2011). Trust cannot just be recognized, but it must be built from the beginning and can be proven.

Product quality and price are positively and significantly influential toward the purchase decision. Consumers' purchase decisions are influenced by the product quality and price (Rafdinal, 2019). The most important tool for interaction between product and consumer, and therefore is the most important element of consumer's judgement on product quality (Savelli et al., 2019). In the context of online stores, products with various qualities and prices are offered on many online markets. It confirms that every online store needs to pay attention to the product quality and price in order to compete and increase the purchase decision.

Based on this result, it can be stated that one's shopping activity is not because of the ease of use of the application but rather the rational factors such as perceived usefulness, lifestyle, product quality, price, and trust in online stores. Products are consumers' primary choices in the online stores. It can be viewed from the stores which provide variance of products for daily needs. Online stores must add more distinctive product lines so that consumers are free to make selection. Their trust in shopping is an important matter because the product that will be delivered must be matching with the description on the website, responsive complaint service for the consumers' to submit a claim if the product does not match the description, and transaction safety. The more modern and developing lifestyle also changes the pattern of product purchase by consumers, including buying through online stores. The stores have to analyze the change in lifestyle in marketing their products.

\section{Conclusion}

The use of technology regarding perceived usefulness has a significant influence on attitude. Conversely, the perception of perceived ease of use does not. It reveals that consumers' attitude has no significant effect on attitude. It confirms that their attitude will emerge from the benefit they receive from the purchase. It indicates that attitude influences the purchase decision in the online stores. Even though TAM is not fully accepted, this result has confirmed that online stores applications which are able to benefit consumers will form an attitude which will influence the purchase decision.

On personal factors, lifestyle and trust influence the purchase decision. Therefore, it can be concluded that consumers' personal factors are crucial matters for the marketers to give attention to, in order to be able to influence them in buying products in the online stores. Then, product quality and price have a high influence toward the purchase decision. Every store must make selections on high quality products offered to consumers. It can be viewed from the product rating and comments from the previous customers. In addition, the price should have more attention as it will determine consumers' interest

\section{References}

Ahmed, R. R. (2015). Influence of lifestyle and cultural values on impulse buying behavior. SSRN Electronic Journal, 10, 30-38. https://doi.org/10.2139/ssrn.2656033 
Badan Pusat Statistik. (2019). Statistik e-commerce 2019. In Badan Pusat Statistik. https://www.bps.go.id/publication/2019/12/18/fd1e96b05342e479a83917c6/statistik-ecommerce-2019.html

Blackwell, R. D., Miniard, P. W., \& Engel, F. J. (2006). Consumer Behaviour. Thomson.

Boonlertvanich, K. (2019). Service quality, satisfaction, trust, and loyalty: the moderating role of mainbank and wealth status. International Journal of Bank Marketing, 37(1), 278-302. https://doi.org/10.1108/IJBM-02-2018-0021

Chaturvedi, S., Gupta, S., \& Hada, D. S. (2016). Perceived risk, trust and information seeking behavior as antecedents of online apparel buying behavior in India: An exploratory study in context of Rajasthan. International Review of Management and Marketing, 6(4), 935-943. https://doi.org/10.2139/ssrn.3204971

Chin, W. W., Peterson, R. A., \& Brown, S. P. (2008). Structural equation modeling in marketing: Some practical reminders. Journal of Marketing Theory and Practice, 16(4), 287-298.

Cooper, P. L. (1984). The assessment of writing ability: A review of research. ETS Research Report Series, 1984(1), i-46. https://doi.org/10.1002/j.2330-8516.1984.tb00052.x

Davis, F. D. (1989). Perceived usefulness, perceived ease of use, and user acceptance of information technology. MIS Quarterly, 13(3), 319-340.

Hair, J. E., Hult, G. T., Ringle, C. M., \& Sarstedt, M. (2017). A primer on partial least squares structural equation modeling (PLS-SEM) (2nd ed.). Sage.

Hamari, J., \& Keronen, L. (2017). Why do people play games? A meta-analysis. International Journal of Information Management, 37, 125-141. https://doi.org/10.1016/j.ijinfomgt.2017.01.006

Han, H. (2015). Customer retention in the medical tourism industry: Impact of quality, satisfaction, trust, and price reasonableness. Tourism Management, 46, 20-29. https://doi.org/10.1016/j.tourman.2014.06.003

Hashim, N., \& Hamzah, M. I. (2014). 7P's: A literature review of Islamic marketing and contemporary marketing mix. Procedia - Social and Behavioral Sciences, 130, 155-159. https://doi.org/10.1016/j.sbspro.2014.04.019

Havighurst, R. J., \& Feigenbaum, K. (1959). Leisure and life style. American Sociologist, 64, 396-404.

Hawkins, D. I., Best, R. J., \& Coney, K. A. (2001). Consumer behavior: Building marketing strategy. Irwin/McGraw Hill.

Hong, I. B. (2011). The impact of consumer trust on attitudinal loyalty and purchase intentions in B2C e-marketplaces: Intermediary trust vs. seller trust. International Journal of Information Management, 31(5), 469-479. https://doi.org/10.1016/j.ijinfomgt.2011.02.001

Hosseini, M., \& Norouzi, H. (2017). Investigating the impact of consumer trust on loyalty and purchase intention of food store brands: Case study: Palladium shopping mall in Tehran. International Review of Management and Marketing, 7(4), 138-146.

Howard, J. . (1989). Consumer Behavior in Marketing Strategy. Prentice-Hall.

Išoraite, M. (2016). Marketing mix theoretical aspects. International Journal of ResearchGranthaalayah, 4(6), 25-37. https://doi.org/10.5281/zenodo.56533

Kukar-Kinney, M., Ridgway, N. M., \& Monroe, K. B. (2012). The role of price in the behavior and purchase decisions of compulsive buyers. Journal of Retailing, 88(1), 63-71. https://doi.org/10.1016/j.jretai.2011.02.004

Lee, M., Tsai, T., Lee, M., \& Tsai, T. (2010). What drives people to continue to play online games? An extension of technology model and theory of planned behavior. International Journal of HumanComputer Interaction, 26(6), 601-620. https://doi.org/10.1080/10447311003781318

Lee, W. I., Cheng, S. Y., \& Shih, Y. T. (2017). Effects among product attributes, involvement, wordof-mouth, and purchase intention in online shopping. Asia Pacific Management Review, 22(4), 223-229. https://doi.org/10.1016/j.apmrv.2017.07.007

Lew, S., \& Sulaiman, Z. (2014). Consumer purchase intention toward products made in Malaysia vs. Made in China: A conceptual paper. Procedia - Social and Behavioral Sciences, 130, 37-45. https://doi.org/10.1016/j.sbspro.2014.04.005

Mohmed, S. I., Azizan, B., \& Jali, Z. (2013). The impact of trust and past experience on intention to purchase in e-commerce. International Journal of Engineering Research and Development, 7(10), $28-35$. 
Pogorelova, E. V., Yakhneeva, I. V., \& Agafonova, A. N. (2016). Marketing mix for e-commerce. International Journal of Environmental and Science Education, 11(14), 6744-6759.

Rafdinal, W. (2019). Increasing purchase decisions on palm oil seeds through marketing mix and trust. Advances in Social Science, Education and Humanities Research, 354, 192-198. https://doi.org/10.2991/icastss-19.2019.41

Rainwater, L., Coleman, R., \& Handel, G. (1959). Working Man's Wife: Her Personality, World, and Life Style. Oceania.

Savelli, E., Murmura, F., Liberatore, L., Casolani, N., \& Bravi, L. (2019). Consumer attitude and behaviour towards food quality among the young ones: empirical evidences from a survey. Total Quality Management and Business Excellence, 30(1-2), 169-183. https://doi.org/10.1080/14783363.2017.1300055

Tasin, N. B. (2017). Factors influecing customer's trust in online shopping among executives in a bank. Malaysian Journal of Social Sciences and Humanities (MJSSH), 2(3), 46-59.

Vatjanasaregagul, L., \& Thammathirat, S. (2007). The Impact Of Service Quality And Consumer Decision Factors On Brand Equity. International Business \& Economics Research Journal, 6(3), 97-104.

Wang, C., \& Chen, C. (2009). The impact of knowledge and trust on e-consumers' online shopping activities : An empirical study. Journal of Computers, 4(1), 11-18.

Wang, X., \& Goh, D. H. L. (2017). Video game acceptance: A meta-analysis of the extended technology acceptance model. Cyberpsychology, Behavior, and Social Networking, 20(11), 662-671. https://doi.org/10.1089/cyber.2017.0086

Yang, Y., Asaad, Y., \& Dwivedi, Y. (2017). Examining the impact of gamification on intention of engagement and brand attitude in the marketing context. Computers in Human Behavior, 73, 459469. https://doi.org/10.1016/j.chb.2017.03.066

Yousafzai, S. Y., Foxall, G. R., \& Pallister, J. G. (2010). Explaining internet banking behavior: Theory of reasoned action, theory of planned behavior, or technology acceptance model. Journal of Applied Social Psychology, 40(5), 1172-1202.

Zeithaml, V. A. (1988). Consumer perceptions of price, quality, and value. Journal of Marketing, 52(3), $2-22$.

*Corespondence email:

sharnuke.asrilsyak@lecturer.unri.ac.id 